\title{
Cost of Justice and Exclusion
}

\author{
Ahmad Sohaib \\ School of Economics, QAU Islamabad, Pakistan \\ Muhammad Shafique \\ Hailey College of Commerce, University of the Punjab, Lahore, Pakistan \\ Hafiz Fawad Ali \\ Institute of Business Administration, \\ University of the Punjab, Lahore, Pakistan \\ Yasir Iftikhar \\ N.C.B.A\&E \\ Kashif Nadeem \\ NUML
}

Doi:10.19044/esj.2019.v15n11p1 ～URL:http://dx.doi.org/10.19044/esj.2019.v15n11p1

\begin{abstract}
The main objective of an economic system is to help people in satisfying the basic necessities of life without compromising an individual's freedom. However, almost every society in the world depicts a clear division among people. Some individuals have access to all facilities required for a decent life, while others are excluded from having such facilities. This paper focuses on testing whether this is the case with the judicial system of Pakistan. Based on the philosophical approach towards life, this paper assumes that the foundation on which the current judicial system has been evolved is exclusive in its nature. The paper attempts to show that the exclusive nature of the judiciary cannot become inclusive until we bring the philosophy of the current economic system in line with reality. The paper claims that the philosophy of the current economic system protects the interest of rich and wealthy people. Hence, all sub-systems such as political, judicial, and executive mainly facilitate and promote the welfare of rich people. The final outcome is in favor of those who are wealthy and have high intercept in the society in terms of money and social capital (links with influential people such as politicians/bureaucrats/army generals, etc.). On the other hand, the intuitional framework of the judiciary is less likely to help those who fall into the group of people who do not have money and social capital. The paper test the presumptions empirically based on the primary data collected from Lawyers in the district courts of Islamabad. Here we compare the cost of various types of cases across courts with the average income of an average family. The
\end{abstract}


average cost of almost all types of cases is higher than the average income of an average family. This shows the excludability of the judicial structure of Pakistan. The average family income is calculated from Household Integrated Economics Survey (HIES). The study suggests that a judicial structure with the agents having primary objective of settling the disputes of people are required. The current structure has flaw as it link earnings with the disputes of people. We need a society where the ills of one such as diseases, disputes, weakness, etc., should not become the source of earning for others. The study also claims that until we develop such a society, the true spirit of justice will remain a mere dream for the excluded people.

Keywords: Justice, Excludability, courts, judiciary, lawyers

\subsection{Introduction}

Neoclassical school of thought assumes that individuals are efficient enough to solve their problems without the support of others. That is, the motive of private interest is enough to provide a solution for the problems in society. According to this theory, an individual interacts with others provided that such interaction is beneficial to both of them. However, mutually beneficial interaction is possible in market exchanges where both sides enjoy some surplus benefits. Conflicts are like a negative-sum game; therefore, it is the responsibility of the society to provide a mechanism for its early settlements to avoid loss of efficiency. All organized society of the world has, thus, assigned the tasks of disputes settlement to an institution called judiciary.

The primary objective of any judiciary in society is to help people in settling their disputes within a short period of time with low or no cost. However, the philosophy of neoclassical economics has played a key role in the development of a judicial system across the world in general and Pakistan in particular. Pakistan owned British law (India Act, 1935) and, after some amendments, they have enforced it since independence. Therefore, the organizational structure of the judiciary and the rules of almost all its constituents are obtained from the rules of the British system. In the current judicial system, people involved in disputes are allowed to seek the solution based on the market forces. In other words, the forces of demand and supply are working in the attainment of justice.

The market between a lawyer and client bears most of the attributes of any other goods market, and this makes justice like a commodity which only the rich can afford. Thus, this resulted in a significant increase in the likelihood of the ratio of excluded people from having access to justice. To test the hypothesis of our work, we collected primary data from the district courts of Islamabad. The collected data were analyzed to calculate the level of exclusion of people who have no access to justice. 


\subsection{Literature Review}

Lawyer's fee is an important factor of the cost of litigation. Worthington and Baker (1993) conducted a study in Australia to identify the cost of litigation. Their main focus was on the lawyer's fee for the defendant and forthe plaintiff. They collected the data of 100 firms from New South Wales and Victoria. They also calculated the average cost bore by the defendants and litigants. For litigant, the median fee of a lawyer was $\$ 4,700$ and $\$ 6,000$ in New South Wales and Victoria respectively. The mean fee of the lawyer for litigant was $\$ 7,500$ and $\$ 10,650$ in New South Wales and Victoria respectively. The defendants face the median lawyer fee which amounted to $\$ 4,200$ in New South Wales and $\$ 8,000$ in Victoria. Mean fee for defendant in New South Wales was $\$ 9,000$ and $\$ 11,450$ in Victoria. It can be observed easily that the defendant pays a higher fee than litigant. The uniqueness of this study is that it finds the statistics for litigants and defendants separately. They also compared cost and benefits for both parties. Plaintiffs' cost was $29 \%$ and $26 \%$ of what they got in return, respectively. They also observed that the higher the benefit is attached, the higher the cost in absolute terms. However, when it was calculated in the relative terms, as the amount recovered increases the relative cost decreases.

A lawyer's fee is an important part of the cost of litigation, but there are also other costs included in the cost of justice. Researchers also focused on these types of costs as Kakalik and Pace (1986) estimated the total cost of tort litigation in America in 1985. He estimated the cost of all types bore by the plaintiff, defendant, operating costs of the courts, and the cost faced by insurance companies. They used two different methods to get estimates. The first method was "starting with insurance industry aggregate data on direct losses and expenses paid in 1985, adding self-insurance, and then separating out payments for claims that were not lawsuits." They got second estimates "from the bottom up, starting with data from surveys of individual tort lawsuits, appropriately adjusting the numbers to 1985, and then multiplying it by the number of tort lawsuits terminated." The yearly expenses of all types of tort litigation are from $\$ 29$ billion to $\$ 36$ billion for defendants. The total cost is from $\$ 8$ to $\$ 10$ billion, of which $\$ 4.7$ to $\$ 5.7$ billion is paid to lawyers including other related expenses. There is also $\$ 0.8$ billion for insurance company claim and $\$ 2.5$ to $\$ 3.5$ billion for time cost and other expenses.

Plaintiffs' total cost is in the range of $\$ 6$ to $\$ 8$ billion. The time cost accounts for almost $\$ 1$ billion. $\$ 7,300$ to $\$ 8,800$ is paid by the plaintiffs for lawsuit legal expenses. This is almost $31 \%$ of the total amount he receives in the context of the claim. Plaintiff receives \$21 to \$25 billion in total, of which he gets $\$ 14$ to $\$ 16$ billion in the net. To transfer this net compensation to the litigant, the system consumes the amount of $\$ 16$ to $\$ 19$ billion (including all 
types of expenses), of which, $\$ 11$ to $\$ 13$ billion is the total of litigant and plaintiffs expenses. The fees paid to courts in the context of tort litigation are $\$ 0.5$ billion and $\$ 4$ to $\$ 5$ billion is the total time cost. The plaintiff receives $56 \%$ of total expenses occurred by all parties. The cost faced by the defendant is higher than the litigant and the case is like Australia (the study of Worthington and Baker). These findings are consistent with the previous ones in terms of cost-benefit analysis as well (29\% and $31 \%$ cost-benefit ratio is almost the same). The public expenditure is very small as compared to the overall private expenditure for tort litigation.

The cost to the clients and what they get in return is also investigated (benefit of litigation). Trubek et al. (1983) examined the factors affecting the time spent by lawyers in different cases. For this purpose, they collected the data from lawyers (survey) and CLRP (Civil Litigation research project) from the USA. There are two types of lawyers: I) Those who charge an an hourly basis; II) Those who charge regardless of time. Time was used as the dependent variable to check the effect of 29 different variables for both models. The $\mathrm{R}^{2}$ for an hourly lawyer was 0.45 and 0.35 fora non-hourly lawyer. This means that the same factors have more effect in regards to the hourly lawyers than the non-hourly lawyers. These results show that lawyers are selfish. They also investigated that the litigation "pays" by recovery to fee ratio tool. The plaintiffs get more benefit than the cost they bore. Plaintiffs also receive something (net benefit) in $89 \%$ of cases. Although not all, most of the defendant also got more benefits than cost. However, the defendant's results do not follow a pattern. In the case of recoveries under $\$ 10,000$, the fees and the recovery are almost equal. Nevertheless, in the case where recoveries are more than $\$ 10,000$, the recovery exceeds the fees paid to the lawyers. The study also explains the complaining behavior of society. They found out that $71.8 \%$ of people complained against the defendant party and $63 \%$ of cases reached a dispute, while the remaining cases were solved mutually. $11.2 \%$ of cases were filed in the courts. They also found out the dispute concerning the amount of $\$ 1,000$, and only $10 \%$ are filed to the court. The remaining $90 \%$ are resolved mutually without filing to the court. Most filed cases were "post-divorce" cases and these are $59 \%$ of overall litigation. $28 \%$ of cases were solved by investing 8-24 hours totally on cases by the lawyers.

As far as it is a question of the net benefit of the plaintiff, in this regard, the above three studies have shown that the litigation is beneficial to the plaintiff and it seems to be a reasonable allocation of his resources. For defendants, the calculations do not follow a specific pattern and these are depicting the blur picture of the scenario. Basically, the defendant does not initiate a case, but he is compelled to be involved and the main concern of the defendant should be to minimize his cost. This is why it is a challenge to 
calculate the cost-benefit ratio for the defendant. The defendant's interest should be involved quickly which would lead to a cheap termination of the case.

In addition, researchers discussed monetary cost as well as nonmonetary cost. Semple (2015) examined the private cost of civil justice, the time required to solve cases of different nature, and health cost as well. For this purpose, he conducted interviews on 250 litigants which involved different types of cases from Ontario, British Columbia, and Alberta. The lawyers charge on an average from \$204 to \$386 per hour. He claimed that this fee is about $50 \%$ higher than the fees charged in Canada. He also argued that the monetary cost, which is the most dominated part, is the fee of lawyers. The time required to solve a case varies from case to case. $23 \%$ out of the cases related to land/house and $55 \%$ out of all cases related to personal injuries prolonged for more than 3 years. More so, $27 \%$ of respondents of family cases reported that it took more than a year to resolve a problem. Clients are also faced with some psychological issues, and $79.9 \%$ sentiments were negative like damages to relatives, anger, stress, humiliation, hopelessness, and frustration. $34 \%$ of family lawyers said that they provide services free of charge. Furthermore, he suggested the initiatives at the public and private level which are required to reduce this cost. Public sector initiatives are like restrictions on the lawyers' fee and it increases the competition. The objective of the private initiative is to understand the legal structure, attain legal education, and understand how to deal with their cases themselves.

\subsection{Theoretical Framework}

Neoclassical school of thought explains that the market is a better place for the efficient allocation of resources. Individuals show their willingness to pay in the market through demand, and supplier shows their willingness for acceptance through supply. The optimal outcome is seen when the goods flow towards those who need it the most. This will result in competition in the market for the goods. This competition will exclude those whose willingness to pay is low, therefore leaving space for those whose willingness to pay is high. On the other side of the market, competition among suppliers will exclude those whose willingness to accept is high and leaving space for those whose willingness to accept is low. This process will create a match (equilibrium) between suppliers with the low willingness of acceptance and high willingness to pay. Thus, this produces a surplus which is enjoyed by those who are willing to pay more but in reality, they pay less. This is also related to those whose willingness to accept is low but in reality, they receive more than that. In exercising justice in the market, there is a demand side (litigants) for those seeking justice and who are willing to pay the price for it. On the other hand, there is a supply side (producer) in the form of lawyers who 
are willing to produce justice with some given price. The competition among litigants increases the willingness to pay, and the competition among suppliers decreases the willingness to accept. Hence, equilibrium is reached at a level where only those that can achieve access to justice pay the price. All those people who are in the demand pool but cannot pay the equilibrium price are excluded from having access to justice.

Figure 1 shows the market equilibrium, and the demand for justice comes from the consumer's (client/litigant) side. The supply of justice comes from the producer of justice (lawyers). Therefore, one can raise the question that since lawyers are not the direct producers of justice, but are facilitators, why then are they regarded as suppliers? The answer to this question shows that it is true that they are not direct producers of justice, but without their help, the demand side on an average cannot achieve justice in the judicial structure of Pakistan. Hence, we term them as suppliers. The price of access to justice is determined by the market equilibrium. Those people that can afford the price are provided access to justice, while the rest are denied justice. Thus, they are excluded from the market.

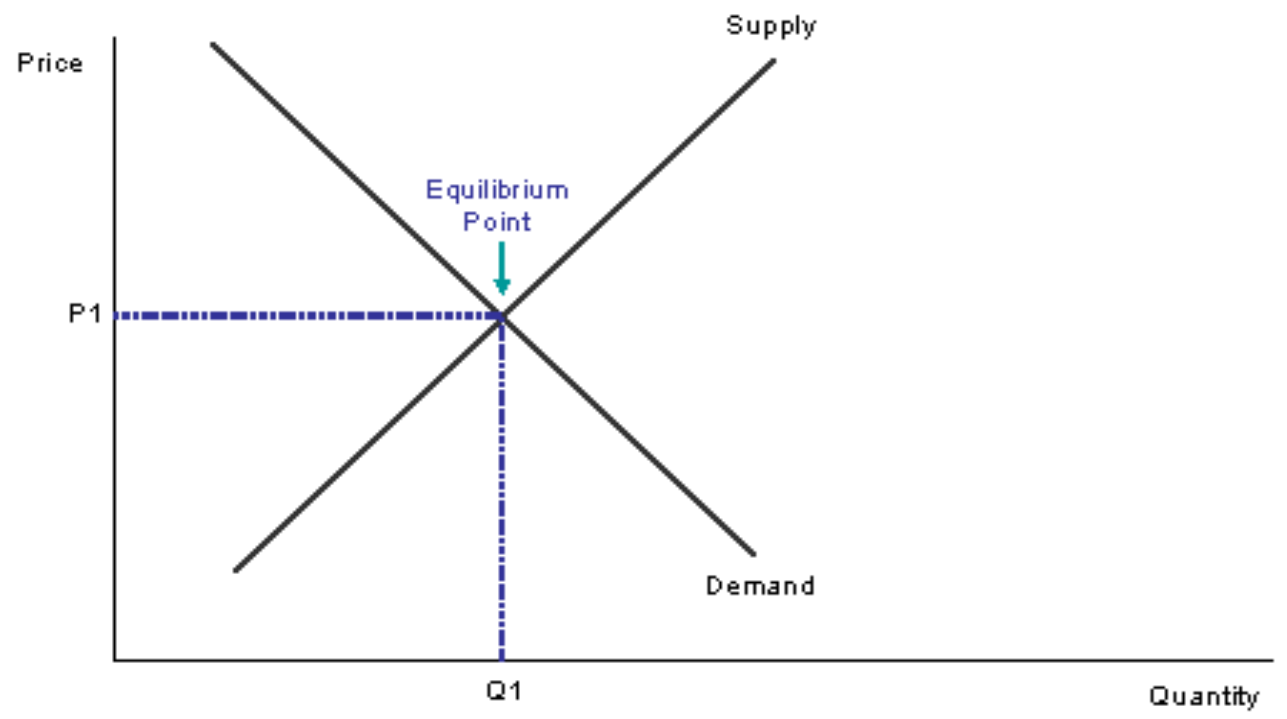

Figure 1. Equilibrium of a Commodity Market

It is also worth mentioning that the above analysis is true if there is the existence of competition. However, the market of justice does not fulfill the requirement of the competition. There is also incomplete information as well as monopoly power with the lawyers. The market structure either becomes a perfect monopoly or near to monopolistic competition where every supplier can charge a price that is different from the price of another supplier, and even for goods that are not much different from the goods supplied by others in the market. The market can also become like a tourist mode where the supplier 
lands in the shop of another supplier and does not have the incentive to switch because switching is costly in terms of searching cost. This makes the supplier rigid in bargaining, and he charges a price where exclusion becomes much higher.

The addition of lawyers in the process of access to justice is a hurdle for the demand side. In reality, it is people who demand justice. Hence, they need someone who should settle their dispute without becoming a party in their disputes. In addition, they must not have monetary benefits attached to the disputes of people. The inclusion of lawyers also makes justice inaccessible as they have monetary benefits attached to the disputes of people. The longer the disputes, the higher the monetary benefits of lawyers. The higher the severity of disputes, the higher (inelastic) the demand for quick resolution of the disputes (land issues), and this, in turn, leads to higher monetary demand by lawyers. The compulsion/constraints of the litigant make the market attractive for lawyers and this makes access to justice costly. Based on the above discussion, we consider that the justice market is not competitive and exclusion is likely to be high. We are interested to find the equilibrium price of justice by collecting data from the field to test the following hypothesis.

3.1 Hypothesis: The price of justice is likely to be high in the noncompetitive market of justice leading to a higher level of exclusion.

\subsection{Data}

We collected primary data to test the hypothesis with a convenient sampling technique. The main objective of the questionnaire was to explore the price of justice (Monetary and Non-Monetary) in various types of courts. For this purpose, we carried out a descriptive and regression analysis.

\subsection{Econometric Model}

An econometric model allows the quantifying of the effect of various factors on the cost of justice. The following equation provides details of the econometric model we used for the purpose of regression.

\section{$\beta_{6}$ PROEX $+\varepsilon$}

CJi $=\alpha+\beta_{1}$ HEXPE $+\beta_{2}$ MAR $+\beta_{3}$ LLM $+\beta 4 O E X P+\beta_{5}$ SENI +

Where I vary from 1 to 5 . It takes a value of 1 for Civil court, 2 for District court, 3 for High court, 4 for Supreme Court, and 5 for Tribunal/services court. All variables are explained in Table 1 below. 
Table 1. Description of the Variables

\begin{tabular}{|c|c|c|}
\hline Variables & $\begin{array}{l}\text { Abbrevi } \\
\text { ation }\end{array}$ & Description \\
\hline $\begin{array}{l}\text { Cost of } \\
\text { Justice }\end{array}$ & $C J_{i}$ & $\begin{array}{l}\text { The monetary cost of litigation in different types of courts in Rs. I vary } \\
\text { with } \\
\text { the type of court. }\end{array}$ \\
\hline $\begin{array}{l}\text { Household } \\
\text { Expenses }\end{array}$ & HEXPE & $\begin{array}{l}\text { Household expenses faced by lawyers in Rs. (hundreds). It is expected } \\
\text { that household expenses have a positive effect on the cost of justice. } \\
\text { MAR is a dummy variable and takes the value of } 1 \text { if the lawyer is }\end{array}$ \\
\hline $\begin{array}{l}\text { Marital } \\
\text { Status }\end{array}$ & MAR & $\begin{array}{c}\text { married, } \\
\text { zero otherwise. We assume that a married lawyer charges a higher fee } \\
\text { than an unmarried lawyer. }\end{array}$ \\
\hline LLM & LLM & $\begin{array}{l}\text { LLM is a dummy variable, and it takes the value of } 1 \text { if the lawyer holds } \\
\text { LLM degree, otherwise zero. It is expected that the lawyer having LLM } \\
\text { the degree will charge a higher fee. }\end{array}$ \\
\hline $\begin{array}{l}\text { Other } \\
\text { Experience }\end{array}$ & EXP & $\begin{array}{l}\text { EXP is a dummy variable, and it takes the value of } 1 \text { if the lawyer has any } \\
\text { other experience like teaching, civil service, any other profession, } \\
\text { otherwise zero. We assume that the lawyer having this type of } \\
\text { experience charges a higher fee than an inexperienced lawyer. }\end{array}$ \\
\hline $\begin{array}{l}\text { Status of } \\
\text { lawyer }\end{array}$ & SENI & $\begin{array}{l}\text { SENI is a dummy variable, and it takes the value of } 1 \text { if the lawyer is } \\
\text { senior, } \\
\text { otherwise zero. We assume that the fee of a senior lawyer is likely } \\
\text { to be high. Hence, we expect a positive sign of cost with SENI. }\end{array}$ \\
\hline $\begin{array}{l}\text { Professional } \\
\text { Expenses }\end{array}$ & PROEX & $\begin{array}{l}\text { Professional Expenses/case faced by lawyers in Rs. (hundreds). } \\
\text { It is expected that professional expenses have a positive impact on } \\
\text { cost of justice. }\end{array}$ \\
\hline
\end{tabular}

\subsection{Results}

In this section, firstly, we will provide an overview of the results. Then we will explain the various types of costs on various types of cases. Furthermore, we will explain how the average Pakistani is excluded from having access to justice by comparing the average earnings of an individual with the average cost of a case. Finally, we will conclude that without changingthe institutional infrastructure of the judicial system of Pakistan, we may not bring inclusiveness.

\subsection{An Overview of the Findings}

Table 2 presents an overview of the various types of cost associated with the different levels of courts. The table highlights the monetary and nonmonetary cost per the case in a court.

It is evident from the table that a litigant has to wait on an average of 3 to 4 years to settle a case in the Civil/Magisterial court. In addition, during these 3 to 4 years, he has to appear 36 times before the court for the hearing of the case. It is also important that for 15 out of 36 times, the litigants observe postponement without hearing. This may happen due to the absence of lawyers or another party, absence of the judge or any other reason. In addition, after 
waiting for 3 to 4 years, the litigants have to wait for another 3 to 4 years for the complete disposition of the case. During this time, he has to bear Rs.50,955 in lieu of lawyers' fee only. When we add up other costs such as the cost of transportation, lodging, and meal, the price of justice shifts upward.

Table 2. Monetary and Non-Monetary Cost Per Case Across Courts

\begin{tabular}{cllllll}
\hline & $\begin{array}{l}\text { The } \\
\text { average } \\
\text { fee } \\
\text { charged } \\
\text { by a } \\
\text { lawyer } \\
\text { (Rs.) }\end{array}$ & $\begin{array}{l}\text { Other } \\
\text { costs } \\
\text { per } \\
\text { case } \\
\text { (Rs.) }\end{array}$ & $\begin{array}{l}\text { The } \\
\text { average } \\
\text { duration } \\
\text { of a case } \\
\text { (in } \\
\text { years) }\end{array}$ & $\begin{array}{l}\text { The } \\
\text { average } \\
\text { number } \\
\text { of } \\
\text { hearings } \\
\text { per case }\end{array}$ & $\begin{array}{l}\text { The average } \\
\text { number of } \\
\text { postponement } \\
\text { of hearings } \\
\text { per case }\end{array}$ & $\begin{array}{l}\text { The } \\
\text { total life } \\
\text { of a case } \\
\text { from } \\
\text { start to } \\
\text { end (in } \\
\text { years) }\end{array}$ \\
\hline $\begin{array}{c}\text { Civil/Magisterial } \\
\text { Court }\end{array}$ & 50,955 & 47,244 & 3.3 & 36 & 15 & 6.4 \\
$\begin{array}{c}\text { District } \\
\text { Court/Court of } \\
\text { Session }\end{array}$ & 63,054 & 56,625 & 2.7 & 26 & 11 & 5.9 \\
$\begin{array}{c}\text { High Court } \\
\text { Supreme Court }\end{array}$ & 106,049 & 126,405 & 1.9 & 9 & 6 & 7.4 \\
Tribunals/Service & 236,903 & 267,885 & 1.5 & 3 & 6 & 7.1 \\
Court & 70,358 & 54,793 & 2.1 & 16 & 5 & 2.9 \\
\hline
\end{tabular}

We calculated the affordability of people from purchasing power, and we also took data from the household integrated economic survey (HIES). The data showed that the average citizen of Pakistan earns Rs.35,662 per month. Hence, if by chance he/she succumbs to a case in the civil court and magisterial court, he/she is less likely to bear the price which includes both the fee of the lawyer and other costs. Table 3 is constructed on the basis of data from HIES of 2016 (Published by Pakistan Bureau of Statistics). The table shows the monthly income and expenditures of the average Pakistani household. The overall average monthly income of a household is Rs.35,662. The average monthly income of a household in rural areas is Rs.30,110, while the average monthly income of the urban household is Rs.45,283. On the other hand, the average monthly expenditures of the household are Rs.32,578. For rural household, it is Rs.27,414 and Rs.41,529 for the urban household. On the basis of this information, the average income of a household per year is Rs.427,944. In the same way, the average income of a household in rural and urban areas is Rs.361,321 and Rs. 543,396, consecutively. Furthermore, the average expenditures are Rs.328,968 per year for a rural household and Rs.498,348 per year for an urban household. A rural household spends $91.04 \%$ of his income on daily expenses, while an urban household spends $91.70 \%$ of his income on daily expenses.

The leftover earnings of a household per year are Rs.37,008. For the rural and urban household, this amount of average saving per year is Rs.32,353 
and Rs.45,048, respectively. In case a household, irrespective of being from rural or urban areas, faces a legal issue in Civil Court, he may not be able to afford the fee of a lawyer in this court which is Rs.50,954. We have mentioned before the minimum level of a lawyer's fee in the Civil Courts. Therefore, we can say that access to justice is hard if not impossible in civil courts for an average Pakistani citizen. This shows that on average, every Pakistani has to either borrow or unload their assets to fight a case in courts. It is worth mentioning that the calculation is based on the assumption that a household faces legal issue once in a year. Thus, the calculation about exclusion will become misleading by relaxing on the supposed assumption.

Table 3 Average Income and Expenditures of Households Per Month in Rs.

\begin{tabular}{cccc}
\hline & Total & Rural & Urban \\
\hline Average Income & 35,662 & 30,110 & 45,283 \\
Average Expenditures & 32,578 & 27,414 & 41,529 \\
\hline
\end{tabular}

We also explained in details the types of cost associated with the cases in different courts.

\subsection{Average Fee of Lawyers Across Courts}

Figure 2 shows the average fee a lawyer charges from the client for the cases in different courts and the other monetary costs. We can see that the average fee of a lawyer for cases in civil courts is Rs.50,955. The amount for a case increases to Rs.63,054 in District Courts/Magisterial Courts. The fee also increases to Rs.70,358 for a case in the Tribunal Court. It further rises to Rs.106,049 for a case in High court. The fee per case takes multiple increases, and it reaches the figure of Rs.236,903 for a case in Supreme Court.

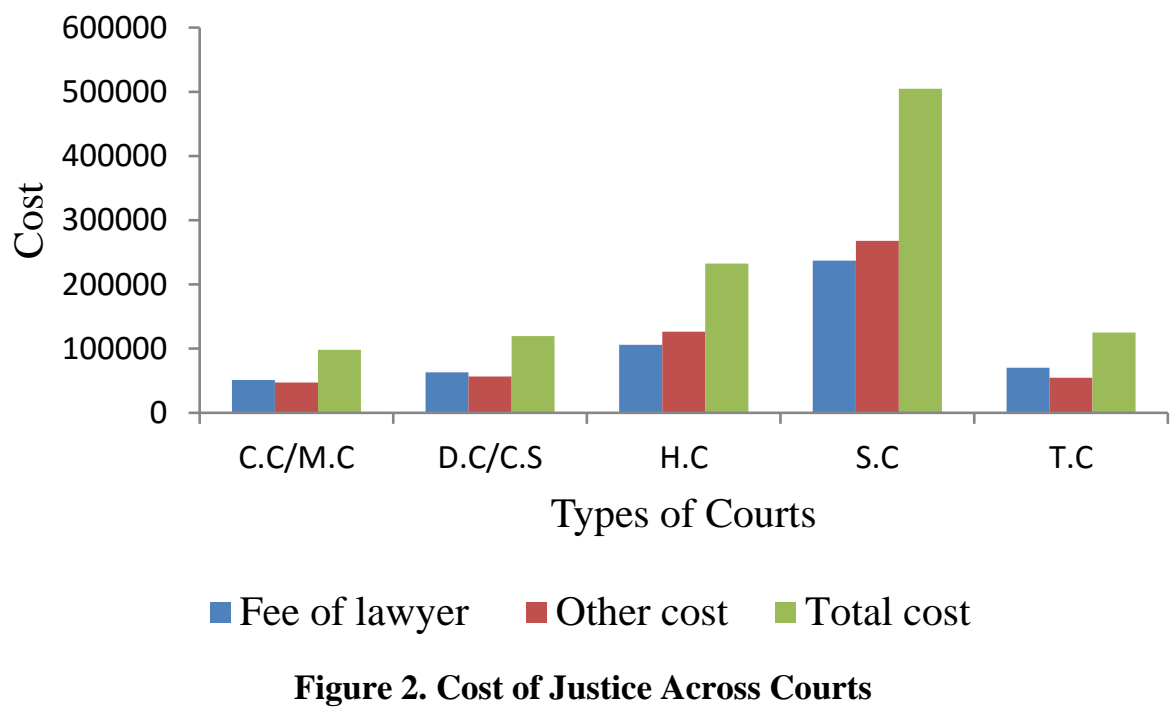


One can observe that the highest amount of fee a lawyer charge is for a case in the Supreme Courts (SC). A lawyer requests for Rs.236,903 per fighting a case in SC. This shows that the price of justice is very high in the Supreme Court. Hence, a higher proportion of the population is denied access to justice from the Supreme Court. Without bearing the fee of a lawyer, an average Pakistani is even unable to file a case in the Supreme Court. This also indicates how much deterrence an average Pakistani citizen might feel in a case where he has to seek justice from the Supreme Court. Therefore, an average Pakistani would knock the door of the SC in exceptional cases. On the other hand, access to justice is not an issue for the rich segment of society in Pakistan. They can easily afford the fee of a lawyer to file cases in the Supreme Court. ${ }^{1}$

The situation regarding excludability from access to justice in other courts is also not very satisfactory. The average fee of a lawyer in all types of courts is beyond the means of an average citizen of Pakistan.

Apart from the lower fee, there are other expenses which a client has to bear. This includes, but not limited to, the charges of documentation, photocopy, tip to the assistant lawyer and other junior staff of the courts, traveling, meal and food expenses, rental expenses for hiring accommodation, etc. The data shows that the amount of such expenses for a case in the civil court is Rs.47,244. Likewise, the amount of such expenses for a case in the district court is Rs.56,625, while for a case in Tribunal Court it is Rs.54,793. The level of such amount increases to Rs.126,405 for a case in High Court and reaches Rs.267,885 per case in SC.

It is noteworthy that Figure 2 shows the value of the average fee of lawyers. There are many types of lawyers and the value of the fee of each type of lawyer is different from the value of the fee of other types of lawyers. Table 4 depicts the average fee of each type of lawyer.

Table 4. Average Fee of Various Types of Lawyers Across Courts in Rs

\begin{tabular}{cccccc}
\hline $\begin{array}{c}\text { Types of } \\
\text { lawyers } \backslash \text { Types of } \\
\text { Courts }\end{array}$ & Senior & Junior & Part-time & Full time & Famous \\
\hline $\begin{array}{c}\text { Civil courts/Magisterial } \\
\text { Courts }\end{array}$ & 56,562 & 36,000 & 41,805 & 54,032 & 123,882 \\
$\begin{array}{c}\text { District Courts/Court } \\
\text { of Session }\end{array}$ & 65,916 & 55,368 & 49,264 & 67,476 & 293,058 \\
$\quad$ High Court & 123,358 & 54,121 & 84,852 & 113,403 & 881,666 \\
$\begin{array}{c}\text { Supreme Court } \\
\text { Tribunals/ Service }\end{array}$ & 260,150 & 100,000 & 250,000 & 234,384 & 802,857 \\
Courts & 73,205 & 44,375 & 72,857 & 69,483 & 260,000 \\
\hline
\end{tabular}

${ }^{1}$ This is the reason why the criticism of "justice for sale" arise against this judicial system. 
The general perception that a junior lawyer charges a fewer fee than the senior lawyer is supported by the data in our study. Experience pays to a lawyer who charges more than a junior lawyer. Therefore, when experience reaches the level of popularity, it pays much more. This can be seen from the table that the fee of a famous lawyer is much higher than the rest of the categories.

Additionally, there are some lawyers who practice part-time in the courts. The table shows that the fee of part-time lawyers on average is lower than the fee of full-time lawyers. In the Civil Court, full-time lawyers charge Rs.54,032 per case and part-time lawyers charge Rs.41,805 per case on average. Full-time lawyers and part-time lawyers charge on average Rs.67,476 and Rs.49,264 respectively in District court/Session court. For the cases of the high court, full time and part-time lawyers charge on average Rs.113,403 and Rs.84,852 respectively. In the above-mentioned courts, the fee of part-time lawyers is lower than the fee of full-time lawyers. However, the situation is different for the cases in SC and Tribunals Court. In the supreme court, the full-time and the part-time lawyer charges on average Rs.234,384 and Rs.250,000 respectively. Here, the fee of part-time lawyers is higher than the fee of full-time lawyers. One of the probable reasons is because part-time lawyers are more specialized in the cases of SC and they may not file cases in the lower courts. In the same manner, full-time lawyers charge lower than the part-time lawyers in Tribunal Courts. The average fee charged by the parttime lawyers in the tribunals/services courts is Rs.72,857, while it is Rs.69,483 for a full-time lawyer.

\subsection{Average Number of Hearings and Postponement Across Courts}

A number of hearing is another determinant of monetary and nonmonetary cost. On every hearing, the client has to appear before the judge. The client also has to produce witnesses in some hearings. The presence of a lawyer is mandatory for each hearing. For each hearing, the client is likely to bear many expenses such as the expenses on travel, food, and refreshment. Likewise, he has to pay the expenses of people who come along with him. Sometimes, the client might pay compensation to witnesses, pay extra to please the lawyers (other than the fee), offer some amount for documentation and other expenses. We showed the detail of such cost in Figure 5.3.1, which depicts the number of hearings and postponements per case across different courts. 


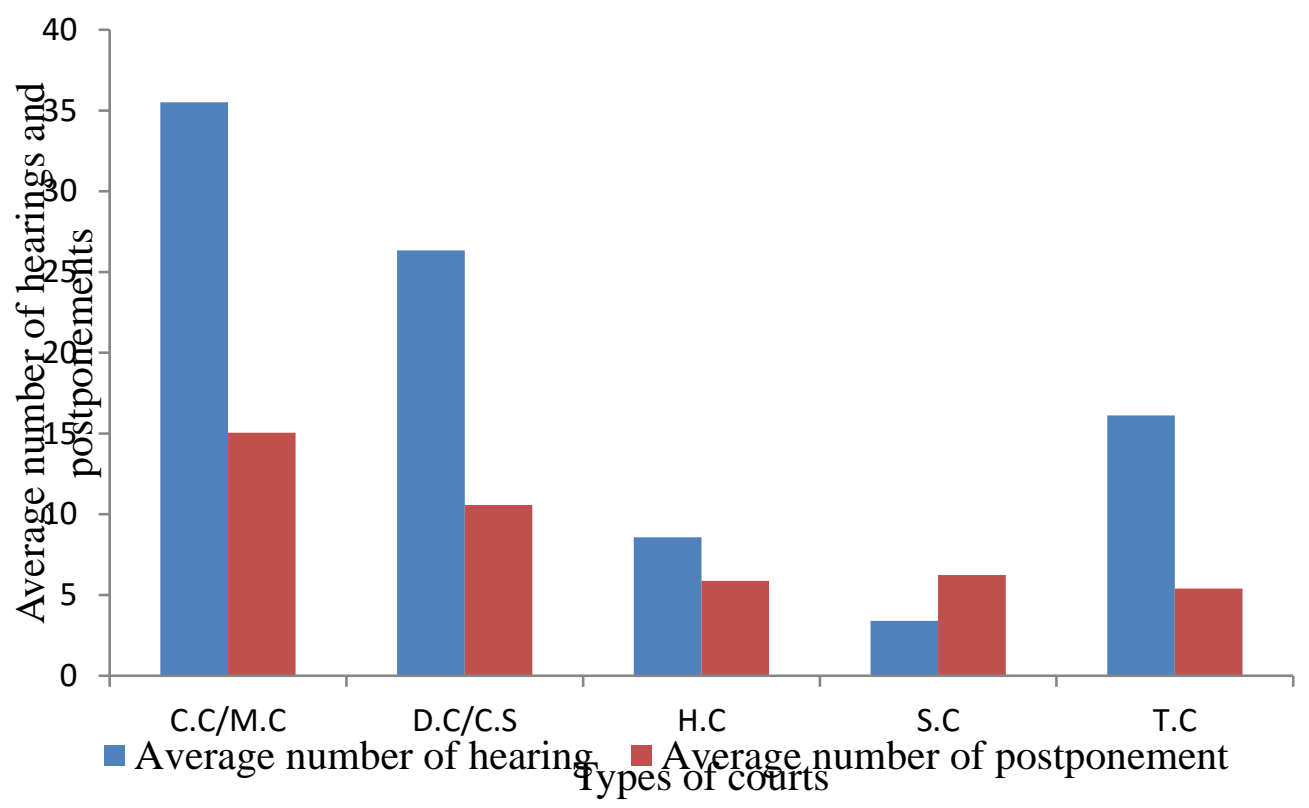

Figure 3. Average Number of Hearings and Postponement (court wise)

The client has to bear the highest number of hearing in Civil and Magisterial court. The second highest number of hearing a client has to bear is in the district court and the Court of Session followed by tribunal court.

In the District Court/Court of the session, the average number of hearing, as well as postponement, is 26 and 11, consecutively. However, in the tribunal court, the number of hearing is 16 . The figure also shows that the lowest number of hearing (3) and postponement (6) is in the Supreme Court followed by the high court where the number of hearing is 9 and postponement is 6 . This shows that in terms of monetary cost, the fee of a lawyer is highest in SC however; in terms of hearing this cost is low. We can claim that the higher monetary cost of a case in SC is canceled out by the low number of hearings (opportunity cost). On the other hand, the fee of lawyers is low in Civil Court/Magisterial court. Nevertheless, the low fee of a lawyer is canceled out by the higher number of hearing in the same courts. The low level of the number of hearing in the Supreme Court shows that poor people will prefer cases in supreme courts due to the opportunity cost in lower courts (Civil Court/Magisterial court and District court/Court of Session). Hence, excludability increases for a client who is rich, but a poor client in lower courts cannot spare time to attend each hearing.

\subsection{The Average Duration of a Case Across Courts}

Figure 5.4.1 shows the average duration of a case across courts. We find that the longer average duration of a case is in the Civil Court followed 
by the District Courts. The average duration of a case in civil court is 3 years and 3 months, while in the district court it is 2 years and 9 months. However, the average duration of a case in courts other than these two types of courts is low. It is 1 year and 11 months in high court and 1 year and 6 months in SC. In tribunals court, it is 2 years and 1 month. We have mentioned earlier that it is not the average duration of a case that matters for clients in terms of nonmonetary cost. It is the number of total hearing that matters to them. The reason is that length,as well as the number of hearing, determines the opportunity cost of waiting or struggling to get justice. On one hand, the number of average duration of the cases in civil court is high. On the other hand, the number of hearing of a case in civil court is more in number than in other courts. This dual level of cost increases the excludability of people from access to justice. Hence, we can say that access to justice not only depends on the fee of a lawyer, but it also depends on the time, a number of hearing, and postponement of a case. The higher the cost of a case, the higher the excludability from access to justice.

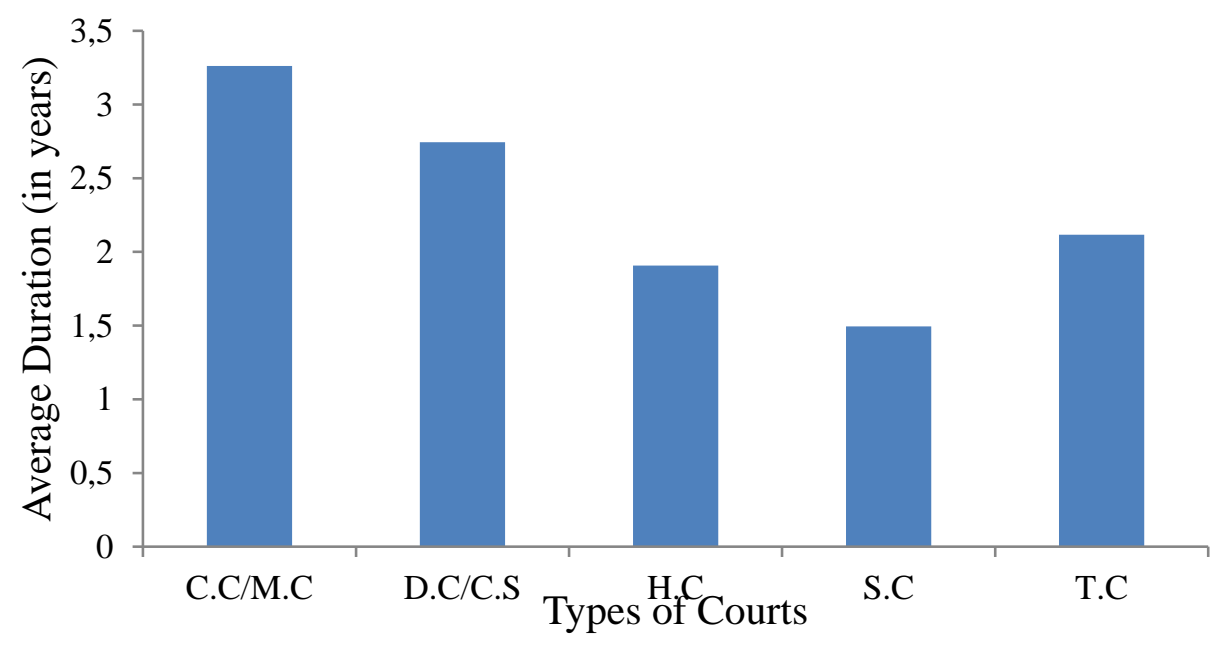

Figure 4. Average Duration of the Case

\subsection{Regression Analysis}

In this section, we provided findings of the regression analysis. It has been discussed that it is the price of justice that plays a key role in excluding people from having access to justice. Hence, we calculated the price of justice by adding the direct and indirect cost incurred on a case in different courts.

\section{$\beta_{6}$ PROEX $+\varepsilon$}

$$
\mathrm{CJi}=\alpha+\beta_{1} \text { HEXPE }+\beta_{2} \text { MAR }+\beta_{3} L L M+\beta_{4} \text { OEXP }+\beta_{5} \text { SENI }+
$$

The results of the regressions are given in Table 5 below. 
Table 5. Regression Results

\begin{tabular}{|c|c|c|c|c|c|}
\hline Variables & $\begin{array}{c}\text { Civil/Magistrate } \\
\text { Courts }\end{array}$ & $\begin{array}{c}\text { District/Session } \\
\text { Courts }\end{array}$ & $\begin{array}{l}\text { High } \\
\text { court }\end{array}$ & $\begin{array}{l}\text { Supreme } \\
\text { Court }\end{array}$ & $\begin{array}{c}\text { Tribunals/Service } \\
\text { Courts }\end{array}$ \\
\hline $\begin{array}{l}\text { Household } \\
\text { expense }\end{array}$ & $\begin{array}{c}0.00044 \\
(0.000296)\end{array}$ & $\begin{array}{c}0.00042 * * \\
(0.00019)\end{array}$ & $\begin{array}{l}0.00051^{*} \\
(0.00022)\end{array}$ & $\begin{array}{l}0.00091 \\
(.00094)\end{array}$ & $\begin{array}{c}0.00078 * * * \\
(0.00025)\end{array}$ \\
\hline $\begin{array}{c}\text { Marital } \\
\text { status }\end{array}$ & $\begin{array}{c}0.56 \\
(0.76)\end{array}$ & $\begin{array}{l}-0.018 \\
(0.412)\end{array}$ & $\begin{array}{c}0.20 \\
(0.35)\end{array}$ & $\begin{array}{l}0.71 \\
(0.43)\end{array}$ & $\begin{array}{c}0.35 \\
(0.34)\end{array}$ \\
\hline LLM & $\begin{array}{l}-0.18 \\
(0.32)\end{array}$ & $\begin{array}{c}-0.60 * * * \\
(0.199)\end{array}$ & $\begin{array}{c}-0.61 * * * \\
(0.23)\end{array}$ & $\begin{array}{l}-1.06 \\
(0.66)\end{array}$ & $\begin{array}{c}-0.91 * * * \\
(0.30)\end{array}$ \\
\hline $\begin{array}{c}\text { Other } \\
\text { Experience }\end{array}$ & $\begin{array}{l}-0.54 \\
(0.34)\end{array}$ & $\begin{array}{l}-0.059 \\
(0.172)\end{array}$ & $\begin{array}{l}-0.34 * \\
(0.184)\end{array}$ & $\begin{array}{l}-0.41 \\
(0.30)\end{array}$ & $\begin{array}{l}-0.27 \\
(0.24)\end{array}$ \\
\hline Senior & $\begin{array}{l}0.95 \\
(0.81)\end{array}$ & $\begin{array}{l}0.25 \\
(0.40)\end{array}$ & $\begin{array}{c}0.93 * * * \\
(0.30)\end{array}$ & $\begin{array}{c}1.44 * * * \\
(0.43)\end{array}$ & $\begin{array}{l}0.73 * \\
(0.38)\end{array}$ \\
\hline $\begin{array}{l}\text { Professional } \\
\text { Expenses }\end{array}$ & $\begin{array}{c}0.00035 \\
(0.00026)\end{array}$ & $\begin{array}{l}0.00028^{*} \\
(0.00015)\end{array}$ & $\begin{array}{l}0.000070 \\
(0.00017)\end{array}$ & $\begin{array}{l}-0.00039 \\
(0.00030)\end{array}$ & $\begin{array}{l}.000029 \\
(.00025)\end{array}$ \\
\hline CONS & $\begin{array}{c}9.81 * * * \\
(0.77)\end{array}$ & $\begin{array}{c}10.67 * * * \\
(0.40)\end{array}$ & $\begin{array}{c}10.65^{* * * *} \\
(0.32)\end{array}$ & $\begin{array}{c}11.11 * * * \\
(0.51)\end{array}$ & $\begin{array}{c}10.33^{* * *} \\
(0.40)\end{array}$ \\
\hline $\begin{array}{l}\text { Number of } \\
\text { Observation }\end{array}$ & 145 & 142 & 131 & 62 & 84 \\
\hline $\begin{array}{l}\text { R-square } \\
\text { F-statistics }\end{array}$ & $\begin{array}{l}0.11 \\
0.0025\end{array}$ & $\begin{array}{l}0.10 \\
0.0020\end{array}$ & $\begin{array}{l}0.20 \\
0.0000\end{array}$ & $\begin{array}{l}0.23 \\
0.0001\end{array}$ & $\begin{array}{l}0.24 \\
0.0003\end{array}$ \\
\hline
\end{tabular}

Note: standard errors appear in parenthesis. Where * shows significance at $10 \%$, ** shows significance at $5 \%$ and $* * *$ shows significance at $1 \%$.

On an average, we found out the estimates per expectation. For example, the role of household expenses, senior and professional expenses, and LLM is significant. Household expenses significantly led to the cost of justice in district courts, high court, and tribunals. When there is an increase of Rs. 100 in the household expenses of a lawyer, we expect an increase in the cost of justice by $0.04 \%, 0.05 \%$, and $0.07 \%$ in the district court, high court, and Supreme Court respectively. Significantly, the coefficient of this variable is very small; there would be a reason why the lawyer charges a lump sum fee from his client. The status of a lawyer is also a determinant of the cost of justice and a dummy variable was being introduced to check the effect of the senior ship. Effect of the senior ship is significant in the high court, Supreme Court, and in tribunals. If the lawyer is senior, then the cost of justice will increase on average by $93 \%, 144 \%$, and $73 \%$ in the high court, Supreme Court, and in tribunals respectively. Senior lawyers have a reputation among clients and courts. Therefore, this high charge of fees by a senior lawyer may be due to their goodwill.

However, we find the sign of LLM in contrast to what we assume. The probable reason is due to the limited market for a higher educated lawyer. The lawyers with LLB degree have a rush of cases on their desk because most of the litigants perceive that they may charge less. Nevertheless, higher demand for their services makes them more known in the market. This may be one of 
the reasons why they charge more. In the case of more qualified lawyers (in our study LLM), most of the clients perceive that they may charge more than an LLB lawyer. Therefore, they may have fewer cases on their tables. This is due to the reason that they may have undersized demand. As a result of this, the lawyers may charge less to get as many clients as they can and to broaden their goodwill for clients. This variable is significant in the district courts, high court, and in tribunals. If a lawyer possesses an LLM degree, then the cost of justice will decrease on average by $60 \%$ in district courts, $61 \%$ in the high court, and $91 \%$ in the Supreme Court. The lawyer's fee is part of the cost of justice, hence it affects the cost of justice level. Professional expenses are significantly responsible for the cost of justice in the district courts only. If there is an increase of Rs.100 in professional expenses, then we expect an increase in the cost of justice for district court by $0.02 \%$.

However, we do not find any role of marital status and other experience. Marital status of a lawyer is not significantly responsible for the cost of justice for any court. This means that whether a lawyer is married or single, his status will not affect the cost of justice. This is because the most important determinant of the lawyer's fee is their experience in the relevant field (law practice). Consequently, the marital status of a lawyer does not affect his remuneration. Other experiences do not affect the cost of justice significantly except in the case of the high court. If a lawyer has such experience, he will charge 34\% less than the lawyer who does not have such experience. The probable reason for his lower fee may be that he also has another source of income, so he charges low.

The main variable which plays a role in determining the cost of justice is household expenses, LLM, and senior. In the same manner, the signs of the coefficients are also in line with our expectation. However, the signs of LLM and other experiences are opposite to our expectations. So, we can say that the factors which are significant are currently affecting the level of excludability because there is a change in the level of the price of justice.

\subsection{Conclusion}

The findings of this study are based on descriptive analysis and regression analysis. The main findings of this study showed the average fee charged by the lawyer which is not in the affordability level of the citizens of Pakistan. On the basis of the HIES report, Pakistani's consume more than 91\% of their incomes and the saving behavior is very low in the nation. The remaining $9 \%$ of their income is not sufficient even for the lawyer's fee. The minimum average fee across different types of courts is Rs.50,955. The rural household saves on average Rs.32,353 annually and the urban household saves on average Rs.45,028 annually. The saving of households is less than the fees charged by the lawyer. Therefore, one cannot afford even less expensive court 
case. On average, a Pakistani national cannot afford even a lawyer's fee, then how can he afford the remaining costs. Accordingly, this analysis gives the argument that there is a problem of over-exclusion in the judicial system of Pakistan. This over-exclusion indicates that the judicial system of Pakistan follows the neoclassical framework of economics.

\subsection{Policy Implications}

As it is identified in this study, the fee of lawyers is very high and is beyond the affordability of a Pakistan citizen. More so, it is not just a fee for a lawyer, there are other charges like fee of court, charges of documentation, traveling expenses, expenses of food, and all other relevant charges are included in the cost of seeking justice. It is the duty of the government to ensure the delivery of justice to every citizen. In this context, the government should implement some rules to minimize this cost. Pakistan National assembly passed an act named "cost of litigation Act 2017 " to minimize the cost of litigation. This is appreciable, but it is only applicable in Islamabad. However, it should be applicable throughout the country. The state should also formulate policies to minimize the burden of courts. A huge amount of cases is pending in different courts of the country. This tendency is the main reason for the long litigation system. There should be alternative dispute resolution (ADR) institutes (like Jirga, Panchayat within the constitutional and human rights framework) to minimize this burden. Moreover, the National assembly standing Committee on Law approved a bill "out-of-court settlements". According to the bill, the trial courts will appoint the arbitrators with the consent of parties to settle their mutual disputes. The public should be aware of these ADRs so that the problem of exclusion can be avoided. With the appreciation of the ADRs, the fee of the lawyer will be excluded and the burden on the litigant will end. The role of the police is extremely vital in the process because they are the first respondent in most of the cases, therefore they playan effective role which affects the outcome in the judicial process.

\section{References:}

1 Balmer, N. J. \& Pleasence, P. (2012). The legal problems and mental health needs of Youth Advice Service users: the case for advice. London: Youth Access.

2 Balmer, N. J., Pleasence, P., \& Buck, A. (2010). Psychiatric morbidity and people's experience of and response to social problems involving rights. Health \& social care in the community, 18(6), 588597.

3 Dana, J. D. \& Spier, K. E. (1993). Expertise and contingent fees: The role of asymmetric information in attorney compensation. Journal of Law, Economics, \& Organization, 9(2), 349-367. 
4 Danish, R. Q., Shahid, R., \& Ali, H. F. (2019). Factors Affecting life Satisfaction of Employees under Financial Threat. SEISENSE Journal of Management, 2(1), 85-98.

5 Iqbal, A. (2016). Reforming the Alternative Mechanisms of Dispute Resolution in Pakistan.

6 Iqbal, F., Ahmad, M. B., \& Ali, H. F. (2019). Determinants of capital structure: an empirical study of KSE listed MNCs in Pakistan.

7 Kakalik, J. S. \& Pace, N. M. (1986). Costs and compensation paid in tort litigation (p. 37). Institute for Civil Justice, Rand.

8 McDonald, H. M. \& People, J. (2014). Legal capability and inaction for legal problems: knowledge, stress and cost. Updating Justice, 41.

9 Nekokara, M.A. (2016). Access to justice and legal aid. Dawn News. Retrieved from https://www.dawn.com/news/1301948

10 Rosenblum, E. F. (2007). Judicial Ethics for All: An Expansive Approach to Judicial Ethics Education. Justice System Journal, 28(3), 394-404.

11 Stratton, M. \& Anderson, T. (2008). Social, economic and health problems associated with a lack of access to the courts. Canadian Forum on Civil Justice.

12 Sandefur, R. L. (2007). The importance of doing nothing: everyday problems and responses of inaction.

13 Semple, N. (2015). The Cost of Seeking Civil Justice in Canada. Browser Download This Paper.

14 Trubek, D. M., Sarat, A., Felstiner, W. L., \& Kritzer, H. M. (1983). The costs of ordinary litigation. UCLa L. Rev., 31, 72.

15 Worthington, D. \& Baker, J. (1993). The costs of civil litigation: current charging practices, New South Wales and Victoria. Law Foundation of New South Wales.

16 World justice project (2017). The rule of law in Pakistan. Washington, D.C. 